\title{
Barbara Kryk
}

Uniwersytet Szczeciński

e-mail: krykb@wneiz.pl

\section{REALIZACJA PROGRAMU GWARANCJE DLA MLODZIEŻY W POLSCE \\ GUARANTEES FOR THE YOUTH PROGRAM IN POLAND}

DOI: $10.15611 / \mathrm{pn} .2018 .537 .03$

JEL Classification: E24, J6

Streszczenie: Bezrobocie osób młodych jest ogromnym problemem w Unii Europejskiej. By ograniczyć jego rozmiary, wspólnie opracowano specjalny program o nazwie Gwarancje dla młodzieży, mający stanowić remedium na istniejącą sytuację. Program ten wdraża również Polska, stąd celem artykułu jest przedstawienie efektów jego realizacji i ich ocena na podstawie syntetycznych wskaźników ustalonych do monitorowania. Okres badawczy to lata 2012-2017. W artykule wykorzystano metodę analizy aktów prawnych, danych statystycznych, metodę wskaźnikową, analizę porównawczą oraz skalę ocen ,plusowych” określających poziom osiągnięć. Analiza wykazała, że osiągnięto dość zadowalający i średnio zadowalający poziom czterech wskaźników kluczowych do monitorowania efektów, a niezadawalający pozostałych wskaźników. Można zatem powiedzieć, że Program Gwarancje dla młodzieży przyniósł pozytywny efekt i nie jest potrzebne kreowanie nowych programów wspomagających młodzież, lecz doskonalenie istniejących narzędzi aktywizacji.

Słowa kluczowe: gwarancja dla młodzieży, efekty, wskaźniki kluczowe.

Summary: Unemployment among young people is a huge problem in the European Union. To reduce its size, a special program called Guarantees for the Youth was developed jointly to remedy the existing situation. This program is also implemented by Poland, hence the aim of the article is to present the effects of its implementation and their assessment on the basis of synthetic indicators set for monitoring. The research period is 2012-2017. The article uses the method of analysis of legal acts, statistical data, the index method, comparative analysis and the scale of "plus" assessments defining the level of achievements. The analysis showed that a fairly satisfactory and moderately satisfactory level of 4 key indicators to monitor the effects was achieved, and the other indicators were unsatisfactory. It can therefore be said that the Guarantees for the Youth program has had a positive effect and it is not necessary to create new programs supporting youth, only to improve existing activation tools.

Keywords: guarantee for the youth, effects, key indicators. 


\section{Wstęp}

W Unii Europejskiej istnieje wysoki poziom bezrobocia młodzieży. W 2012 r. liczba młodych bezrobotnych wynosiła ok. $5 \mathrm{mln}$, średnia stopa bezrobocia przekraczała $23 \%$, a liczba tzw. NEETs ok. 7,5 mln osób. Równocześnie aż 42,7\% młodych osób posiadało zatrudnienie czasowe, a $31,9 \%$ było zatrudnionych na niepełny etat [Factsheet 2015]. Zła sytuacja młodzieży na rynku pracy zainicjowała 7 lat temu dyskusję pomiędzy politykami, naukowcami i przedsiębiorcami nie tylko o problemie wysokiego bezrobocia młodych, lecz także o zwiększeniu w tej grupie liczby osób nieaktywnych zawodowo i edukacyjnie (tzw. NEET, Not in Education, Employment or Training), braku stabilności zatrudnienia (np. poprzez nadużywanie przez przedsiębiorców umów cywilnoprawnych), problemie młodego prekariatu zawodowego [Krzyminiewska 2015; Niewiadomska 2017] oraz niskich zarobków pozwalających nazwać niektóre grupy młodych pracowników tzw. working poor (biedny/ubogi pracujący). Konsekwencją rozpoczętej wówczas debaty było opracowanie przez państwa wspólnotowe ambitnej strategii na rzecz obniżenia poziomu bezrobocia młodzieży Gwarancja dla młodzieży [Zalecenie Rady z dnia 22 kwietnia 2013...], która jest jedną z najistotniejszych inicjatyw UE mających na celu poprawę sytuacji młodzieży na rynku pracy. Ustanowieniu gwarancji dla młodzieży towarzyszyło stworzenie politycznych wytycznych i wsparcia finansowego na poziomie unijnym, w szczególności poprzez Inicjatywę na rzecz zatrudnienia ludzi młodych [2016].

Wsparcie w ramach Inicjatywy otrzymały regiony na poziomie NUTS-2 o stopie bezrobocia wśród młodych osób w wieku 15-24 lat przekraczającej 25\% w $2012 \mathrm{r}$. ( $\mathrm{z}$ uwzględnieniem młodzieży NEET), a w odniesieniu do państw członkowskich, w których stopa bezrobocia młodzieży wzrosła o ponad 30\% w 2012 r. - regiony na poziomie NUTS-2 o stopie bezrobocia młodzieży wynoszącej ponad 20\% w $2012 \mathrm{r}$. Do finansowania w ramach Inicjatywy na rzecz zatrudnienia ludzi młodych zakwalifikowano 20 państw członkowskich, posiadających regiony odpowiadające kryteriom skorzystania z tej pomocy ${ }^{1}$. Wśród nich była Polska, w której - podobnie jak w całej Unii Europejskiej - sytuacja osób młodych na rynku pracy jest trudniejsza niż pozostałych grup wiekowych. Przejawia się to zarówno wysokim poziomem bezrobocia młodzieży w porównaniu z ogólną stopą bezrobocia w kraju, jak również stosunkowo niskim poziomem aktywności zawodowej w tej grupie wiekowej. Szczególnie istotny jest problem osób młodych pozostających poza edukacją, szkoleniem i zatrudnieniem. To zadecydowało o objęciu Polski pomocą w tym zakresie.

Inicjatywa objęto województwa: dolnośląskie, kujawsko-pomorskie, łódzkie, lubelskie, lubuskie, małopolskie, podkarpackie, świętokrzyskie, warmińsko-mazurskie, zachodniopomorskie [Europejska gwarancja dla młodzieży 2015, s. 15;

${ }^{1}$ Należą do nich Szwecja, Belgia, Irlandia, Zjednoczone Królestwo, Francja, Portugalia, Hiszpania, Włochy, Polska, Czechy, Węgry, Słowacja, Rumunia, Bułgaria, Słowenia, Chorwacja, Grecja, Łotwa, Litwa, Cypr. 
Rozporządzenie Parlamentu Europejskiego 2013]. Polska należała do grupy 7 państw², którym przydzielono największe fundusze na aktywizację młodzieży NEET ${ }^{3}$. Obok środków z Inicjatywy, program Gwarancji dla młodzieży jest finansowany ze środków pochodzących z budżetu UE w ramach Europejskiego Funduszu Społecznego (EFS) za pośrednictwem Programu Operacyjnego Wiedza Edukacja Rozwój ${ }^{4}$ (PO WER 2014-2020) oraz ze środków krajowych. Łącznie na działania na rzecz osób młodych ze środków wspólnotowych okresu programowania 2014-2020 zaplanowano kwotę 2,035 mld euro, w tym 550 ml EUR z Inicjatywy, a ze środków Funduszu Pracy przeznaczonych na aktywizację bezrobotnych przewidziano dla młodych średniorocznie ok. 1,8 mld zł (do dyspozycji urzędów pracy) oraz średniorocznie ok. $52 \mathrm{mln}$ zł (dla Ochotniczych Hufców Pracy, OHP, na realizację zadań ustawowych).

W Polsce w drugim półroczu 2013 r. został opracowany Plan realizacji Gwarancji dla młodzieży [2013], którego faktyczne wdrażanie rozpoczęło się w roku 2014 [Zaktualizowany Plan realizacji 2015]. Zatem minęły już 4 lata od uruchomienia programu Gwarancji wspierającego zdobywanie pracy przez młodych ludzi, warto więc spróbować go ocenić. To zdeterminowało cel artykułu, którym jest przedstawienie efektów realizacji programu w Polsce i ich ocena. Początek okresu badawczego to rok 2012, którego dane o bezrobociu wśród młodzieży stanowiły podstawę decyzji UE o objęciu pomocą z omawianego programu krajów/regionów, dlatego przyjęto go za punkt odniesienia do pokazania zmian w sytuacji młodzieży na rynku pracy $\mathrm{w}$ wyniku działań wówczas zainicjowanych. Koniec okresu badawczego to rok 2017, będący kolejnym rokiem kontynuowania zaktualizowanej w 2016 r. inicjatywy wsparcia aktywizacji społecznej i zawodowej młodych osób z grupy NEET, zagrożonej bezrobociem i wykluczeniem społecznym, zaplanowanej do roku 2022 [Gwarancja dla młodzieży i inicjatywa na rzecz zatrudnienia 2016]. Analiza osiągnięć da również odpowiedź na pytanie, czy prowadzone działania są wystarczające dla obecnych i nowych wyzwań, czy też należy rozważyć nowe? Poza tym ze względu na stosunkową nowość poruszanego zagadnienia jest niedostateczna liczba publikacji naukowych na ten temat, dlatego artykuł stanowi uzupełnienie dostrzeżonej luki badawczej, a zastosowana metoda oceny rozszerza spektrum metod badawczych. Chcąc zaprezentować efekty wdrażania Gwarancji, przeanalizowano obowiązujące wskaźniki kluczowe do ich monitorowania, które uzupełniono kilkoma wskaźnikami syntetycznymi gwoli pełniejszego zobrazowania sytuacji. Umożliwiło to sformułowanie wniosków z oceny i rekomendacji udoskonalających dotychczasowe działania.

${ }^{2}$ Należały do niej również Hiszpania, Włochy, Francja, Wielka Brytania, Grecja i Portugalia (łącznie wraz z Polską otrzymały 81,2\% ogółu środków z Inicjatywy).

$37,9 \%$ z nowej linii budżetu UE przeznaczonej na zatrudnienie ludzi młodych, która wynosiła 3,2 mld euro.

${ }^{4}$ Z PO WER będą wspierane osoby młode we wszystkich województwach, także nieobjętych Inicjatywa. Po wyczerpaniu się środków z Inicjatywy przeznaczonych na wsparcie młodzieży NEET (które muszą zostać wykorzystane do końca 2018 r.) pomoc dla młodych będzie finansowana w całym kraju z EFS. 


\section{Gwarancja dla młodzieży w Polsce}

Gwarancja dla młodzieży to postulat/zobowiązanie, by państwa członkowskie zapewniły ludziom w wieku do 25 lat - w ciągu czterech miesięcy od zakończenia kształcenia formalnego lub uzyskania statusu osoby bezrobotnej - dobrej jakości ofertę zatrudnienia dopasowaną do ich wykształcenia, umiejętności i doświadczenia lub możliwość zdobycia wykształcenia, umiejętności i doświadczenia wymaganych do znalezienia w przyszłości pracy w drodze stażu, przyuczenia do zawodu lub dalszego kształcenia [Europejska gwarancja dla młodzieży: rozpoczęto wdrażanie 2015, s. 12]. Gwarancja dla młodzieży obejmuje wszystkich młodych ludzi niekształcących się, niepracujących ani nieszkolących się (NEET). Grupa osób określanych jako młodzież NEET jest różnorodna i można ją podzielić na dwie szerokie kategorie: bezrobotna młodzież NEET aktywnie szukająca pracy oraz bierna zawodowo młodzież NEET nieszukająca pracy (mniej zmotywowana do podejmowania aktywnych działań i w związku z tym bardziej oddalona od rynku pracy, niekształcąca się ani nieszkoląca) ${ }^{5}$ [Kryk 2018; Bynner, Parsons 2002; Barham i in. 2009, Yates $i$ in. 2011]. W Polsce grupa młodych z kategorii NEET dzieli się niemal po równo na osoby bezrobotne oraz bierne zawodowo (z różnych przyczyn nieposzukujące pracy) [Badanie efektów 2015]. Szczegółowo sytuację młodzieży na rynku pracy w Polsce przed rozpoczęciem wdrażania Gwarancji dla młodzieży przestawiono w opracowaniu Młodzi na rynku pracy - pracownicy, przedsiębiorcy, bezrobotni [Jelonek i in. 2015] oraz Polski rynek pracy - wyzwania i kierunki działań [Górniak (red.) 2015].

Zgodnie z zapisami Planu realizacji Gwarancji dla mtodzieży w Polsce adresatami Gwarancji w latach 2014-2015 były: osoby bezrobotne do 25 r.ż., w szczególności zarejestrowane w powiatowych urzędach pracy; młodzież w wieku 15-17 lat przedwcześnie kończąca naukę; osoby od 18 do 25 r.ż. z grupy NEET; osoby w wieku 18-29 lat objęte systemem pożyczkowym przez Bank Gospodarstwa Krajowego (BGK). Od 2016 r. grupę docelową, do której adresowana jest pomoc w ramach Gwarancji, rozszerzono na osoby do 30 r.ż.

Początkowo działania aktywizacyjne wobec młodych bezrobotnych prowadzone były wyłącznie przez urzędy pracy i OHP. W listopadzie 2014 r. na terytorium całego kraju rozwinięty został program pożyczkowy realizowany przez BGK (wcześniej, w fazie pilotażu, obejmujący jedynie 3 województwa), natomiast w grudniu $2014 \mathrm{r}$.

${ }^{5}$ Wyodrębnienie grupy NEET jest istotne dla pełniejszego zobrazowania udziału ludzi młodych w rynku pracy, albowiem dotychczas stosowane wskaźniki, przede wszystkim dotyczące zatrudnienia i bezrobocia, okazały się niewystarczające dla analizy złożonej kondycji przedstawicieli młodego pokolenia. Koncentracja na grupie NEET pozwala odnieść się do ogółu młodzieży, a nie tylko jej części aktywnej zawodowo. To ukierunkowanie na systematyczne docieranie do młodzieży biernej zawodowo, a nie tylko na wspieraniu młodzieży aktywnie poszukującej pracy, stanowi swoiste novum gwarancji dla młodzieży. Można zatem powiedzieć, że jej celem jest trwała integracja całej młodzieży NEET na rynku pracy. 
nastąpiło oficjalne przyjęcie przez Komisję Europejską PO WER, co otworzyło możliwość finansowania ze środków EFS konkursów centralnych i regionalnych na działania aktywizacyjne dla młodzieży NEET oraz wyłaniania podmiotów niepublicznych do ich prowadzenia.

Wdrożenie Gwarancji wymagało nowelizacji ustawy o promocji zatrudnienia i instytucjach rynku pracy, wraz z wejściem jej w życie (27 maja 2014) w polskie przepisy wpisany został obowiązek udzielenia wsparcia osobom młodym w ciągu 4 miesięcy od rejestracji (wcześniej było to 6 miesięcy) [Ustawa z 14 marca 2014]. Tym samym pod koniec 2014 r. zaistniały warunki prawne i organizacyjne dla realizacji Gwarancji dla młodzieży we wszystkich formach wymienionych w Planie realizacji Gwarancji dla młodzieży w Polsce. Niezależnie od formy, celem wsparcia skierowanego do osób młodych jest zapewnienie spójnej, jednorodnej oferty aktywizacji zawodowo-edukacyjnej dla osób młodych w całym kraju (wieku 15-29 lat), zwłaszcza z kategorii NEET.

\section{Efekty programu w Polsce}

Głównym celem realizacji działań określonych w Gwarancjach dla młodzieży jest poprawa sytuacji młodych ludzi na rynku pracy i to zarówno tych zarejestrowanych w urzędach pracy jako bezrobotne, jak i biernych zawodowo, które mogłyby wejśćl powrócić na rynek. W monitorowaniu sytuacji wykorzystuje się zarówno analizę zmian głównych wskaźników makroekonomicznych opisujących sytuację osób z grupy NEET na rynku pracy (tzw. kluczowych), jak i analizę wszystkich innych przedsięwzięć dotyczących uczestników działań określonych w Gwarancjach dla młodzieży (badane są rezultaty odnośnie do efektywności, skuteczności i statusu uczestników w określonym czasie po zakończeniu tych działań). W artykule przedmiotem badań są wskaźniki kluczowe.

W Zaktualizowanym Planie realizacji Gwarancji dla młodzieży w Polsce [2015, s. 59] do monitorowania rezultatów przyjęto 9 obligatoryjnych wskaźników kluczowych (w tab. 1. oznaczono je cyframi; pochodzą one zarówno z badania BAEL, jak i statystyki bezrobocia rejestrowanego), które autorka - w celu lepszego zobrazowania zachodzących zmian - uzupełniła dodatkowymi wskaźnikami syntetycznymi (są oznaczone literą a). Chcąc zidentyfikować stan osiągnięć Polski w tym zakresie, przeanalizowano wielkość, dynamikę i kierunek zmian wskaźników ${ }^{6}$, a następnie biorąc pod uwagę tempo zmian w tym zakresie - dokonano syntetycznej oceny dotychczasowych osiągnięć w realizacji gwarancji. Do jej wykonania wykorzystano następującą skalę ocen: niezadawalająca $(+)$, średnio zadowalająca $(++)$, dość zadowalająca $(+++)$, zadowalająca $(++++)$. Im wyższy był poziom osiągniętych wskaźników i szybsze tempo ich zmian, tym więcej przyznawano $(+)$.

${ }^{6}$ Należy zauważyć, że przy większości wskaźników występuje brak danych odnośnie do kategorii wiekowej 25-29 lat, co jest związane z odmienną klasyfikacją danych do potrzeb statystycznych. W niektórych przypadkach były tylko dane zbiorcze dla grupy osób młodych i to dopiero od niedawna. 
Rozważania nad efektami wdrażania Gwarancji dla młodzieży warto zacząć od analizy zmian stopy bezrobocia danej kategorii osób. W badanym okresie stopa bezrobocia osób w wieku 15-24 zmniejszyła się prawie o 12 p.p., tj. ponad 44\%. Od 2014 r., gdy zaczęto realizować program, dany wskaźnik zaczął spadać średnio o 3,1\% rocznie. Jeszcze korzystniejsze zmiany obrazuje wskaźnik Eurostatu - zharmonizowana stopa bezrobocia młodzieży - który zmniejszył się o prawie 15 p.p., czyli ponad 52\%. Średniorocznie wskaźnik ten spadał o 3,5\%. Zmiany obu wskaźników są dość zadowalające, tym bardziej że dzięki wspomaganiu ludzi młodych w wejściu na rynek pracy oraz poprawie sytuacji gospodarczej po wcześniejszym ogólnoświatowym kryzysie finansowo-ekonomicznym, od 2014 r. zmniejszała się liczba młodzieży rejestrującej się jako bezrobotni - średnio o $11,5 \%$ rocznie $^{7}$. Towarzyszy temu zmniejszenie odsetka osób do $25 \mathrm{r}$.ż. w ogólnej liczbie zarejestrowanych bezrobotnych o 7,5 p.p. (37,7\%) od 2012 do 2017 r. Średniorocznie ten wskaźnik obniżał się tylko o ok. 1 p.p., co jest wynikiem średnio zadowalającym, ale ma to związek z proporcją między liczbą młodzieży a liczbą osób z innych grup wiekowych wynikającą ze struktury demograficznej społeczeństwa [Badanie efektów 2017]. Potwierdzeniem tego jest wskaźnik 8. odzwierciedlający procentową zmianę liczby bezrobotnych do 25 r.ż. i procentową zmianę liczby bezrobotnych wieku 25-29 w relacji do zmiany ogólnej liczby bezrobotnych, który przez cały okres badawczy zmniejszył się tylko o 0,1 p.p. (9,1\%), a jego wysokość utrzymywała się na zbliżonym poziomie przez wszystkie lata.

Świetnym odzwierciedleniem poprawy sytuacji młodzieży na rynku pracy jest ograniczenie liczby bezrobotnych osób do 25 r.ż. prawie o 290 tys. $(68,3 \%)$ w ciągu 6 lat. Średniorocznie ich liczba zmniejszała się o 48,3 tys., przy czym najmniejsze ograniczenie miało miejsce w 2013 r. (23,2 tys. osób, tj. ok. 8\% ogółu), a największe (o ponad 99 tys. osób, tj. 35\%) w 2014 r., gdy zaczęto wykorzystywać środki pomocowe dla młodych. W pozostałych 3 latach liczba bezrobotnej młodzieży zmniejszała się średnio o ok. 21\%. Zatem zmiany w tym zakresie są dość zadowalające i wskazują, że zwiększył się popyt na pracę w Polsce. Dodatkowym potwierdzeniem pozytywnego oddziaływania działań związanych z realizacją Gwarancji na sytuację młodych osób jest zmniejszenie się liczby bezrobotnych absolwentów prawie o 70\% ( 88,1 tys.) w badanym okresie, co jest dość zadowalające i wskazuje na skuteczność instrumentów stosowanych w odniesieniu do tej grupy, czyli pozwalających uzyskać doświadczenie zawodowe ${ }^{8}$ (typu bony: zatrudnieniowe, stażowe, szkoleniowe, na zasiedlenie) lub dotacje na podejmowanie działalności gospodarczej dla osób posiadających cechy przedsiębiorcze. Towarzyszyło temu zmniejszenie udziału absolwentów w ogólnej liczbie bezrobotnych o 39\% (2,3 p.p.). Zmiana wysokości tego wskaźnika jest średnio zadowalająca, ale jest to spowodowane ograniczeniem liczebności młodzieży z powodu starzenia się społeczeństwa. W przypadku obu

\footnotetext{
${ }^{7}$ Obliczenia własne na podstawie [Sytuacja na rynku pracy osób młodych 2012-2017].

8 Jego brak stanowi duży problem dla młodych w otrzymaniu pracy.
} 
wskaźników największe zmiany nastąpiły po 2013 r., co wyraźnie dowodzi ich związku z realizowanym wsparciem dla młodych.

Niezadowalające są zmiany wskaźnika NEET osób w wieku 15-24. W ciągu 5 lat zmniejszył się on tylko o 1,3 p.p. (11\%). Jego zmiany są dużo mniejsze w porównaniu ze stopą bezrobocia młodzieży z tej samej grupy wiekowej, co sugeruje, że aktywizacja młodzieży z tej grupy nie powiodła się. Pamiętać jednak należy o niejednorodności populacji młodzieży w tej grupie (część jest bierna zawodowo i nie wykazuje chęci do aktywizacji) oraz problemach z zapewnieniem pracy młodym osobom, które często nie posiadają żadnych kwalifikacji lub są one niskie9 .

Ograniczeniu bezrobocia wśród młodzieży w wieku 15-24 lat nie towarzyszyła spektakularna zmiana w aktywności zawodowej tej grupy. Współczynnik aktywności zawodowej osób w tym wieku kształtował się przez cały czas na dość zbliżonym poziomie, w ciągu 6 lat zwiększył się tylko o 1 p.p. (2,9\%), co nie jest zadowalające. Część populacji danej grupy kontynuuje naukę w szkołach ponadpodstawowych i wyższych i praktycznie nie uczestniczy w rynku pracy, a ponieważ w Polsce jest niż demograficzny, to większość osób korzysta z nieodpłatnych form edukacji, nie muszą więc zdobywać na nią funduszy, co ogranicza aktywność zawodową ${ }^{10}$.

Niezadowalające są też zmiany wskaźnika zatrudnienia młodzieży w wieku 15-24 lat, który zwiększył się o 5,1 p.p. (20,6\%) w ciągu 6 lat. Wciąż jest on niższy od średniej unijnej ${ }^{11}$, ale jego zmiana była wyższa od zmiany ogólnopolskiego wskaźnika zatrudnienia w badanym okresie (4,8 p.p.), co pośrednio potwierdza skuteczność programu Gwarancje dla młodzieży.

Dość zadowalający był odsetek osób do 25 r.ż. objętych aktywnymi programami rynku pracy w ogólnej liczbie uczestników aktywnych form. Poziom tego wskaźnika kształtował się na średnim poziomie $32,1 \%$, a w przypadku grupy wiekowej do 30 r.ż. nawet 47,6\%, co oznacza, że młodzież rzeczywiście jest uprzywilejowana w korzystaniu z takich form pomocy. Łącznie w ciągu 6 lat programami aktywnymi objęto ponad 800 tys. osób do 25 r.ż., a średniorocznie 156,8 tys.

Efektem pomocy młodzieży - ale mało zadowalającym, a i to dzięki porównaniu z dłuższym średnim czasem pozostawania bez pracy w Polsce - jest skrócenie średniego czasu pozostawania bez pracy osób do 25 r.ż. do 7,9 miesiąca. Czas ten jest prawie dwukrotnie wyższy od wskazań zawartych w Gwarancji, w której postulo-

${ }^{9}$ Ze Sprawozdania specjalnego nr 5 [2017] Europejskiego Trybunału Obrachunkowego wynika, że w UE-28 nastąpiły równie nieznaczne zmiany wskaźników NEET [Kryk 2018; Tamesberger, Bacher 2014].

${ }_{10}$ Współczynnik aktywności zawodowej osób w wieku 15-19 lat w Polsce wynosił zaledwie 2,7\% na koniec 2016 r. W przypadku całej Unii było to 12\%, a w Danii i Holandii dochodził do prawie 50\%. Wyrównanie unijnego wyniku oznaczałoby wzrost zatrudnienia o 150 tys. kształcących się osób [Linpka 2017].

${ }^{11} \mathrm{~W}$ tym czasie jego średni poziom wynosił $25,8 \%$, podczas gdy w UE $32,8 \%$. Pocieszający jest fakt, że tempo zmian tego wskaźnika w Polsce (średnioroczne 1 p.p.) jest większe niż we Wspólnocie (średnioroczne 0,3 p.p.). 


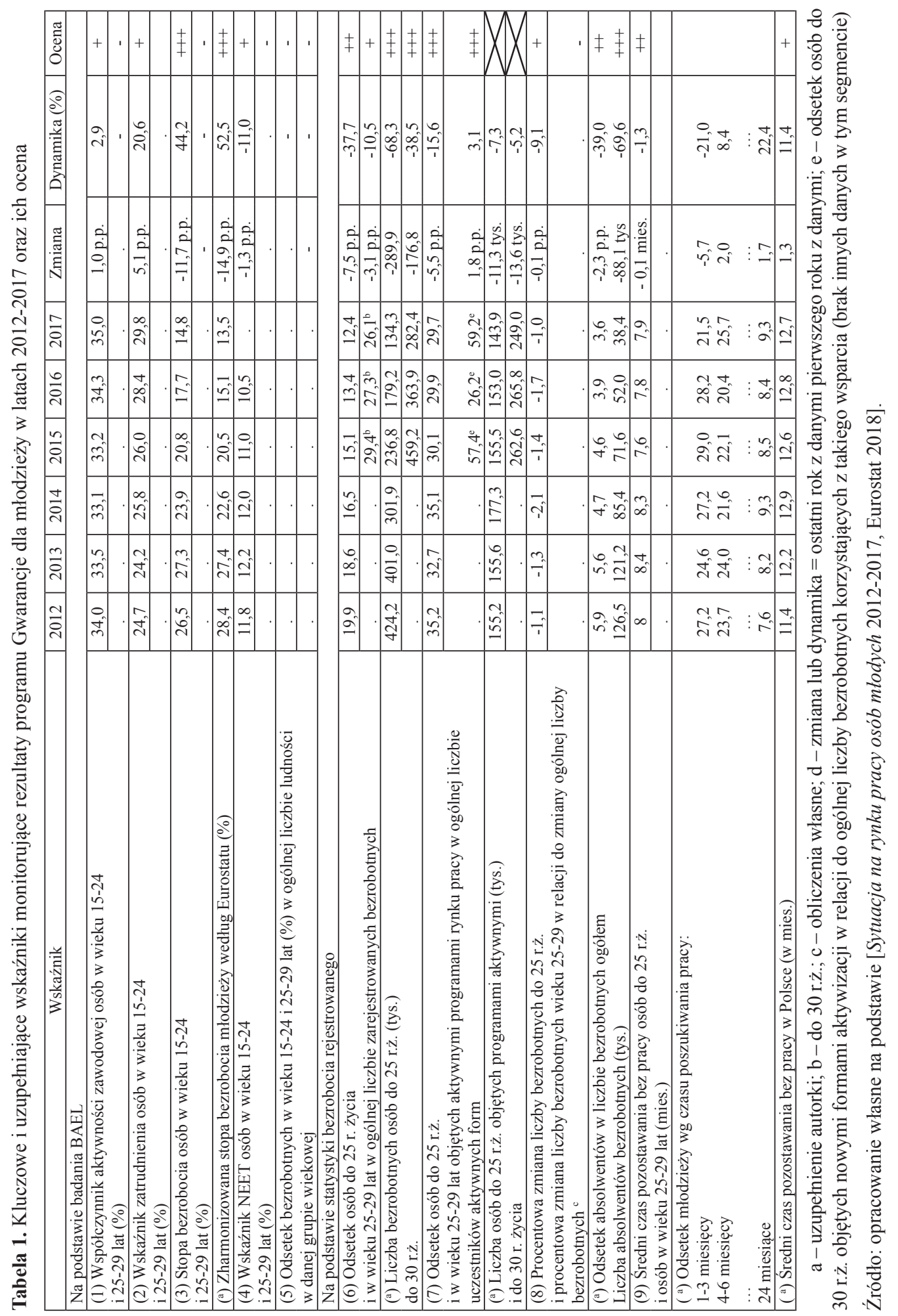


wano, aby młodzieży oferować pracę w ciągu 4 miesięcy od zarejestrowania się. Za korzystne w tym zakresie można jedynie uznać, że ok. 50\% młodzieży poszukującej pracy znajduje ją w czasie od 1 do 3 i 6 miesięcy i jest to czas krótszy w porównaniu $\mathrm{z}$ innymi grupami wiekowymi.

Oceniając efekty programu Gwarancje dla młodzieży, należy również wziąć pod uwagę poprawę koniunktury gospodarczej po zakończeniu kryzysu ekonomiczno-finansowego z lat 2009-2014. Podczas kryzysu współczynnik absorbcji pracujących przez wzrost gospodarczy ${ }^{12}$ wynosił w Polsce 0,37\% [Kotlorz, Sojka 2017], w latach 2015-2017 wyniósł 1,27\% (obliczenia własne), czyli był ponad 3 razy wyższy niż w okresie spowolnienia. Oznacza to, że wzrost gospodarczy zadziałał prozatrudnieniowo na gospodarkę, ale ta zmiana nie była jednolita dla wszystkich podmiotów i sektorów gospodarki. W odniesieniu do młodzieży współczynnik absorbcji pracujących był niższy, bo wyniósł $0,75 \%$. Można zatem powiedzieć, że poprawa sytuacji młodzieży na rynku pracy jest efektem synergicznym działań prowadzonych w ramach programu Gwarancje dla młodzieży i ogólnej poprawy sytuacji gospodarczej w ciągu ostatnich trzech lat.

\section{Zakończenie}

Analiza kluczowych wskaźników służących do monitorowania efektów realizacji programu Gwarancje dla młodzieży wykazała, że w ciągu 5 lat wsparcie młodzieży przyniosło dość zadowalające zmiany wskaźników 3 (zmniejszenie o ponad 44\% stopy bezrobocia osób w wieku 15-24 i 25-29 lat) i 7 (zmniejszenie o 5,5 p.p. odsetka osób do 25 r.ż. objętych aktywnymi programami rynku pracy), średnio zadowalające wskaźników - 6 (zmniejszenie udziału osób do 25 r.ż. o 7,5 p.p. i w wieku 25-29 lat o 3,1 p.p. w ogólnej liczbie zarejestrowanych bezrobotnych) i 9 (skrócenie o 1,3\% średniego czasu pozostawania bez pracy), czyli łącznie czterech z dziewięciu. Zatem w ich przypadku można mówić o skuteczności programu. Zmiany pozostałych wskaźników $(1,2,4,8)$ są niezadawalające ${ }^{13}$. Ich poprawa zależy od wielu różnych czynników, m.in. lepszego dostosowania struktury form wsparcia do struktury osób aktywizowanych, ustalenia, czy chodzi o sukces edukacyjny, czy zatrudnieniowy w odniesieniu do uczestników (często wykluczają się one nawzajem i dla wielu osób docelowo jest osiągalny tylko jeden z nich), dopracowania systemu informacji o osobach opuszczających rejestr bezrobotnych, wprowadzenia preferencji

12 Współczynnik ten obliczany jest jako iloraz procentowego przyrostu zatrudnienia i procentowego przyrostu PKB. Informuje on, o ile procent zmieni się zatrudnienie, jeśli dynamika PKB zmieni się o $1 \%$.

${ }^{13}$ Dla wskaźnika 5. brak danych. Zmiany współczynnika aktywności zawodowej i zatrudnienia młodzieży były mniejsze w porównaniu ze średnią ogólnopolską, wskaźnik NEET zmniejszył się tylko o 11\%, stopa bezrobocia wśród badanej grupy osób jest wciąż wyższa niż przeciętna w kraju, a czas pozostawania bez pracy dłuższy od norm wyznaczonych przez UE. 
w rekrutacji do projektów dla osób z grup, w których obserwowane są największe efekty. W kontekście powyższego można powiedzieć, że nie ma potrzeby kreowania kolejnego rodzaju programu, lepiej udoskonalić ten istniejący.

\section{Literatura}

Badanie efektów wsparcia zrealizowanego na rzecz osób młodych w ramach Programu Operacyjnego Wiedza Edukacja Rozwój, 2015, I Raport Tematyczny, przygotowany przez konsorcjum IBS, MAPP, IQS dla Ministerstwa Infrastruktury i Rozwoju, Warszawa, s. 16.

Badanie efektów wsparcia zrealizowanego na rzecz osób młodych w ramach Programu Operacyjnego Wiedza Edukacja Rozwój. II Raport wskaźnikowy, 2017, Ministerstwo Rozwoju, Warszawa.

Barham C., Walling A., Clancy G., Hicks S., Conn S., 2009, Young people and the labour market, Economic \& Labour Market Review, vol. 3, Issue 4, s. 17-29.

Bynner J., Parsons S., 2002, Social Exclusion and the Transition from School to Work: The Case of Young People Not in Education, Employment, or Training (NEET), Journal of Vocational Behavior, Volume 60, Issue 2, s. 289-309, doi.org/10.1006/jvbe.2001.1868 (28.10.2018).

Europejska gwarancja dla młodzieży: rozpoczęto wdrażanie, lecz wciaż istnieja zagrożenia, Sprawozdanie specjalne, 2015, Europejski Trybunał Obrachunkowy, nr 03.

Eurostat, 2018, http://appsso.eurostat.ec.europa.eu/nui/submitViewTableAction.do i http://ec.europa. eu/eurostat/tgm/table.do?tab=table\&plugin=1\&language=en\&pcode=t2020_41 (1.04.2018).

Factsheet. Addressing youth unemployment in the EU, 2015, European Comission, ec.europa.eu/info/ sites/info/files/file_import/european-semester_thematic-factsheet_youth_employment_pl.pdf [2.11.2018].

Górniak J. (red.), 2015, Polski rynek pracy - wyzwania i kierunki działań, Polska Agencja Rozwoju Przedsiębiorczości Warszawa-Kraków, s. 41-53.

Gwarancja dla młodzieży i inicjatywa na rzecz zatrudnienia ludzi młodych trzy lata później, 2016, Komisja Europejska, COM (2016) 646 final, Bruksela.

Inicjatywa na rzecz zatrudnienia ludzi młodych. Zestawienie informacji - Komunikat dotyczacy gwarancji dla młodzieży i Inicjatywy na rzecz zatrudnienia ludzi młodych: pytania i odpowiedzi (październik 2016 r.), 2016, Komisja Europejska, Strasburg.

Jelonek M., Kasparek K., Magierowski M., 2015, Młodzi na rynku pracy-pracownicy, przedsiębiorcy, bezrobotni. Edukacja a rynek pracy, t. 4, Polska Agencja Rozwoju Przedsiębiorczości, Warszawa, s. 15-46.

Kotlorz D., Sojka E., 2017, Wzrost gospodarczy a zatrudnienie w Polsce w latach 1995-2014, Studia Prawno-Ekonomiczne, t. CV, s. 259-275.

Kryk B., 2018, Czy gwarancja dla młodzieży i inicjatywy na rzecz zatrudnienia ludzi młodych moga stanowić remedium na bezrobocie? [w:] Pancer-Cybulska E., Biegun K. (red.), Czym żyje Unia Europejska? Wybór zagadnień, Wydawnictwo UE we Wrocławiu, Przedstawicielstwo Regionalne Komisji Europejskiej, Wrocław, s. 167-192.

Krzyminiewska G., 2015, Prekariat nowym interesariuszem ekonomii społecznej, Szczecin 2015, Zeszyty Naukowe Uniwersytetu Szczecińskiego. Studia i Prace Wydziału Nauk Ekonomicznych i Zarządzania, nr 41, t. 2, s. 33-41.

Linpka M., 2017, Młodzi Polacy nie garna się do pracy, http://www.polskatimes.pl/strefa-biznesu/ wiadomosci/a/mlodzi-polacy-nie-garna-sie-do-pracy,12706592/ (6.04.2018).

Niewiadomska A., 2017, Prekariat na polskim rynku pracy próba identyfikacji zjawiska, Gospodarka w Praktyce i Teorii, nr 2 (47), s. 58-76.

Plan realizacji Gwarancji dla młodzieży w Polsce, 2013, Ministerstwo Pracy i Polityki Społecznej, Warszawa. 
Program Operacyjny Wiedza Edukacja Rozwój 2014-2020, 2014, MIiR, Warszawa.

Rozporządzenie Parlamentu Europejskiego i Rady (UE) nr 1304/2013 z dnia 17 grudnia 2013 r. w sprawie Europejskiego Funduszu Społecznego i uchylające Rozporządzenie Rady (WE) Nr 1081/2006, Dz.Urz. UE 2013, L 347/470.

Sprawozdanie specjalne nr 5, 2017, Bezrobocie wśród młodzieży-czy polityka UE wptynęła na zmiane sytuacji? Ocena gwarancji dla młodzieży i inicjatywy na rzecz zatrudnienia ludzi młodych, Europejski Trybunał Obrachunkowy.

Sytuacja na rynku pracy osób młodych w roku 2012, 2012, Ministerstwo Pracy i Polityki Społecznej, Warszawa.

Sytuacja na rynku pracy osób młodych w roku 2013, 2013, Ministerstwo Pracy i Polityki Społecznej, Warszawa.

Sytuacja na rynku pracy osób młodych w roku 2014, 2014, Ministerstwo Pracy i Polityki Społecznej, Warszawa.

Sytuacja na rynku pracy osób młodych w roku 2015, 2015, Ministerstwo Rodziny, Pracy i Polityki Społecznej, Warszawa.

Sytuacja na rynku pracy osób młodych w roku 2016, 2016, Ministerstwo Rodziny, Pracy i Polityki Społecznej, Warszawa.

Sytuacja na rynku pracy osób młodych w roku 2017, 2017, Ministerstwo Rodziny, Pracy i Polityki Społecznej, Warszawa.

Tamesberger D., Bacher J., 2014, EET youth in Austria: a typology including socio-demography, labour market behaviour and permanence, Journal of Youth Studies, vol. 17, Issue 9, s. 1239-1259, doi.org/10.1080/13676261.2014.901492 (28.10.2018).

Ustawa z 14 marca 2014 r. o zmianie ustawy o promocji zatrudnienia i instytucjach rynku pracy oraz niektórych innych ustaw, Dz.U. 2014, poz. 598.

Wytyczne dotyczace wdrażania Inicjatywy na rzecz zatrudnienia ludzi młodych, 2014, Komisja Europejska.

Yates S., Harris A., Zabates R., Staff J., 2011, Early Occupational Aspirations and Fractured Transitions: A Study of Entry into 'NEET'Status in the UK, vol. 40, Issue 3, s. 513-534, doi.org/10.1017/ S0047279410000656 (28.10.2018).

Zaktualizowany Plan realizacji Gwarancji dla młodzieży w Polsce, 2015, Ministerstwo Pracy i Polityki Społecznej, Ministerstwo Infrastruktury i Rozwoju, Warszawa.

Zalecenie Rady z dnia 22 kwietnia 2013 r. w sprawie ustanowienia gwarancji dla młodzieży, Dz.U. 2013, C 120 z 26.04.2013, s. 1. (2013/C 120/01), Dz.U. 2013. 